\title{
THE POSITION OF WILD LIFE PRESERVATION IN WEST AFRICA
}

\author{
By D. R. Rosevear \\ Lately Inspector-General of Forests, Nigeria
}

In any country the basic need for wild life preservation is the education of the masses; and this is perhaps especially true of Africa, which has a shorter history of civilization than other continents. Vast sums are spent annually in West Africa on furthering general education, in building new schools and in improving and extending old ones. New universities spring up on all sides, which, like the schools, are full to overflowing with young students eager for knowledge; but though there are lessons in Nature Study, Zoology and Botany, these matters are all too often treated as mere exercises in learning with a view to examination, and tend to concern themselves with the more obscure anatomical features of animals rather than their mode of life. Little emphasis is laid upon bringing home to the boys and girls, the young men and young women, the beauty and cultural value of the living scene around them: the animals, the birds, the trees, the flowers, and the importance of ensuring that the brave new world they are creating is not established in a dull and lifeless countryside. These boys and girls are the teachers and legislators of the not very distant future; ten years at the most will see them persons of considerable influence. It is they who in the States now coming into being will set the tune and engender the spirit which will colour the life of many generations to come. They should be made well-informed and interested in the natural world around them.

At present, perhaps the only educative force in natural history on the plane of ordinary citizens - the people on whose interest and goodwill any movement for the preservation of nature will ultimately depend-is the Nigerian Field Society, which embraces the whole of West Africa and has always counted a small band of keen Africans among its supporters. That Society offers an annual prize in natural history to teachers under training. It is a remarkable and very disappointing fact that in the four years during which this prize has been offered only one solitary entry has been received; it does indeed emphasize the great need for the broadening of biological education and for the stimulation of interest among the young 
in the real Jiving world which has so often become fossilized in botanical and zoological laboratories. Education authorities might well encourage potential teachers in biology to support this praiseworthy and far-sighted scheme.

However, until several decades of useful education have been exercising their full force, protection of nature can for the moment only be ensured by other means - actual prevention of harmful acts and effective legal discouragement of mere destroyers. For this there must be well-qualified and adequate staff ; money also is vital. Despite remarkable progress in other ways, in these aspects of conservation West Africa has not developed so far as East Africa. Protection laws are either non-existent or antiquated and unrealistic; and throughout the whole of West Africa there are very few game wardens, although since taking affairs into their own hands two of the three Nigerian Regional Governments have created such posts. The new administrations, therefore, do not show themselves unreceptive to the idea of wild life protection, and indeed, some of them contrary to much pessimistic expectation, have in the swiftness of this first practical step proved themselves by deeds, not words, to have a lively sense of their responsibilities. There are long established and well honoured departments for the conservation of forest resources. It is but a step to the parallel idea of the conservation of the natural fauna.

New laws, a really adequate and properly qualified staff to carry them into force as well as to act as itinerant educators, and special areas in which game can live in safety are the obvious requirements. Time is getting very short. With peace well established after centuries of inter-tribal warfare and with the prevention and cure of devastating tropical diseases, populations both of man and cattle are increasing at a phenomenal rate. New agricultural methods using machinery in place of the simple native hoe, bring yet further pressure on the land. The drive for wealth, both from inside and outside, leads to the alienation of vast tracts of land to permanent crops such as cocoa, rubber and oil palms, leaving less and less available for day to day food production and for the natural fauna. In economic expansion governments often overlook these repercussions ; and in West Africa the pace is rapid. But if wild animals are to continue to exist they must breed. To breed they must have sanctuary ; and they cannot find sanctuary in a countryside seething with human activity. Nature reserves there must be ; and if they are to be set aside, it is now or never. 